\title{
Integrasi Kurikulum dan Internalisasi Nilai-nilai Pendidikan Islam dalam Membentuk Sikap Religius Siswa
}

\author{
Naily Rohmah \\ Sekolah Tinggi Agama Islam YPBWI Surabaya \\ Email: nelly.raf@gmail.com
}

\begin{abstract}
Abstrak
Kehidupan di era globalisasi memungkinkan sikap religius siswa tergerus. Oleh sebab itu, penting untuk dilakukan internalisasi nilainilai pendidikan Islam sejak pendidikan sekolah dasar. Penelitian ini bertujuan untuk menganalisis integrasi kurikulum berikut proses internalisasi nilai pendidikan Islam dalam membentuk sikap religius siswa. Penelitian ini dilakukan di Sekolah Dasar Islam Terpadu (SDIT) Ghilmani Surabaya dengan menggunakan pendekatan deskriptif kualitatif. Temuan penelitian menunjukkan bahwa kurikulum SDIT Ghilmani Surabaya menggunakan kombinasi dari kurikulum Kementerian Pendidikan Nasional, kurikulum Kementerian Agama, dan kurikulum lokal. Proses internalisasi nilai pendidikan Islam terhadap sikap religius siswa dilakukan dengan cara membujuk, membiasakan, menumbuhkan kesadaran siswa, meningkatkan disiplin serta menjunjung tinggi peraturan sekolah. Sedangkan metode pembelajaran melalui ceramah, bercerita, tanya jawab, demontrasi, menumbuhkan kebiasaan baik, dan keteladanan. Dengan demikian, integrasi kurikulum dan internalisasi nilai-nilai pendidikan Islam di SDIT Ghilmani dapat membentuk siswa yang memiliki sikap religius terpuji, taat pada Allah, peduli kepada sesama, berkepribadian baik, jujur, disiplin dan bertanggungjawab.
\end{abstract}

Kata Kunci: Kurikulum, Nilai Pendidikan Islam, Sikap Religius

\section{Pendahuluan}

Globalisasi yang saat ini sedang terjadi menimbulkan dampak bagi dunia pendidikan, di mana pendidikan adalah wahana untuk menyiapkan sumber daya manusia yang mampu memanfaatkan dan mengendalikan perubahan-perubahan yang diakibatkan adanya proses globalisasi tersebut. ${ }^{1}$ Globalisasi dapat berdampak positif dan negatif pada dunia

1 Mohammad Ali, Pendidikan untuk Pembangunan Nasional: Menuju Bangsa Indonesia yang Mandiri dan Berdaya Saing Tinggi (Jakarta: Grasindo, 2009). 229. 
pendidikan. Dampak positif globalisasi pada dunia pendidikan meliputi: kemudahan akses informasi, terbentuknya sumber daya yang handal dan profesional dan berstandar internasional, pendidikan di Indonesia dapat bersaing dengan negara-negara lain, meningkatkan kualitas tenaga kerja, adanya perubahan struktur dan sistem pendidikan secara cepat. ${ }^{2}$ Sedangkan dampak negatifnya antara lain: menurunnya kualitas moral siswa, meningkatnya kesenjangan sosial, tergerusnya kebudayaan lokal, munculnya tradisi serba cepat dan instan, dan komersialisasi pendidikan. ${ }^{3}$ Masyarakat muslim harus mempersiapkan diri untuk menghadapi globalisasi ini agar dapat memperoleh efek positif globalisasi dan membentengi dari segala efek negatifnya. Cara untuk mempersiapkan diri dalam menghadapi globalisasi ialah dengan memperluas wawasan dan meningkatkan kesadaran, yang paling efektif yaitu melalui pendidikan. ${ }^{4}$

Dalam era globalisasi ini, sistem pendidikan di Indonesia harus mampu melahirkan generasi yang sholeh dan berkrepribadian sekaligus mampu mempu menjawab tantangan perkembangan sains dan teknologi. ${ }^{5}$ Esensi pendidikan adalah proses transfer ilmu, pengetahuan dan nilainilai yang baik, serta keterampilan dari generasi tua pada generasi muda supaya generasi muda mampu bertahan hidup. Beberapa hal yang dapat dilakukan untuk meningkatkan pendidikan Islam dalam era globalisasi yaitu, umat Islam harus mampu memanfaatkan teknologi sebagai sarana jihadnya, umat Islam harus meningkatkan SDM secara terus menerus yang berkualitas Iptek (Ilmu pengetahuan dan teknologi) dan Imtaq (Iman dan Taqwa) secara bersamaan, menjadi individu yang kokoh spiritual, moral dan intelektual, serta merombak sistem pendidikan Islam, mulai dari paradigma, konsep, kerangka kerja dan evaluasi. ${ }^{6}$

Untuk mempersiapkan diri lebih dini dari arus globalisasi, seyogyanya dimulai dari sistem pendidikan sekolah dasar. Proses penghayatan atas nilai-nilai pendidikan Islam perlu untuk ditanamkan agar nilai pendidikan Islam tidak hanya dipahami secarar kognitif saja

2 Mohammad Mustari dan M. Taufiq Rahman, Manajemen Pendidikan (Jakarta: RajaGrafika Persada, 2014), 228.

3 Ilmugeografi.com.10, "Dampak Globalisasi di Bidang Pendidikan beserta contohnya", dalam https://www.google.com/amp/s/ilmugeografi.com/ilmusosial/dampak-globalisasi-di-bidang-pendidikan/amp. Diakses tanggal 2 September 2019

${ }^{4}$ Mustari dan Rahman, Manajemen Pendidikan, 228-229.

5 Dewi Safitri, "Dampak Globalisasi terhadap Pendidikan", Jurnal Al Idarah; Jurnal Manajemen Pendidikan Islam, Vol 1. No 1, (2014): 49-54.

${ }^{6}$ Ali Mahsun, "Pendidikan Islam dalam Arus Globalisasi: Sebuah Kajian Deskriptif Analitis", Episteme, Vol. 8, No. 2, (2013): 259-278. 
namun juga bermakna dan bernilai sehingga diamalkan oleh peserta didik dalam kehidupan sehari-hari. Dengan demikian, harapan untuk membentuk sikap religius siswa dengan pribadi Islami akan dapat tercapai. Generasi yang dihasilkan juga akan memiliki iman dan taqwa berbarengan dengan ilmu pengetahuan dan teknologi. ${ }^{7}$ Oleh karena itu, sangat diperlukan proses internalisasi nilai-nilai pendidikan Islam pada pendidikan dasar.

Menyikapi permasalahan moral siswa, pemerintah melalui Kementerian Pendidikan dan Kebudayaan (Kemendikbud) meluncurkan kurikulum berbasis karakter sebagai solusinya. Kurikulum yang disebut juga Kurikulum 2013 dan mulai diterapkan secara terbatas pada tahun 2013 ini dimaksudkan untuk menyiapkan siswa-siswi yang berkarakter positif, seperti memiliki nilai religius, jujur, toleran, cinta tanah air dan seterusnya. Nilai religius merupakan salah nilai karakter penting yang dikembangkan dalam kurikulum 2013. Aspek penting nilai karakter religius tercermin dari deskripsi nilai ini dalam kurikulum 2013, yaitu sikap dan perilaku yang patuh dalam melaksanakan ajaran agama yang dianutnya, toleran terhadap pelaksanaan ibadah agama lain, dan hidup rukun dengan pemeluk agama lain. ${ }^{8}$ Dari deskripsi ini Achmad Sultoni, memberi penjelasan bahwa apabila seseorang memiliki karakter religius, ia akan menjadi orang yang baik. Sebab orang yang religius bersikap taat dan patuh pada agamanya yang pasti mengajarkan kebaikan. ${ }^{9}$

Dalam penelitian ini, Sekolah Dasar Islam Terpadu (SDIT) Ghilmani Surabaya sengaja dipilih sebagai sasaran penelitian karena beberapa pertimbangan, salah satunya adalah bahwa lembaga ini merupakan sekolah berbasis agama Islam, yang diasumsikan memberi perhatian lebih pada pengembangan sikap religius siswa. Selain itu, SDIT Ghilmani Surabaya termasuk salah satu sekolah dasar berkualitas di Surabaya dengan mengintegrasikan tiga kurikulum sekaligus, yakni kurikulum pendidikan Kemtenerian Pendidikan dan Kebudayaan, Kementerian Agama dan kurikulum lokal sekolah.

Dilihat dari sketsa historis, sebenarnya pada tahun 2003 sudah mulai berdiri Jaringan Sekolah Islam Terpadu dengan 426 unit sekolah.

${ }^{7}$ Lihat A. Suradi, "Penanaman Religiusitas Keislaman Berorientasi pada Pendidikan Multikultural di Sekolah", Jurnal Pendidikan Agama Islam (Journal of Islamic Education Studies), Vol. 8, No. 1 (2018).

${ }^{8}$ Pusat Kurikulum, Pengembangan dan Pendidikan Budaya \& Karakter Bangsa: Pedoman Sekolah (Jakarta: TP, 2009), 9-10.

9 Achmad Sultoni, "Implementasi Kurikulum 2013 Bidang Studi Biologi Dalam Mengembangkan Sikap Religius Siswa Di Madrasah Aliyah", Jurnal Pendidikan Agama Islam (Journal of Islamic Education Studies), Vol. 4, No. 1 (2016). 
Munculnya Sekolah Islam Terpadu ini untuk mengajarkan sedini mungkin nilai-nilai pendidikan Islam dan mencetak generasi muslim yang Qur'ani. Pada tahun 2017, jumlah sekolah Islam terpadu di bawah Jaringan Sekolah Islam Terpadu (JSIT) sudah 2.418 unit sekolah, dan tahun 2019 sudah lebih dari 3000 sekolah se-Indonesia, dan 400 lebih diantaranya terletak di Provinsi Jawa Timur. Berkembangnya Sekolah Islam Terpadu antara lain berusaha menjawab tantangan arus globalisasi, untuk menyiapkan generasi muslim yang Qur'ani, yang berkualitas iptek dan imtaq secara bersamaan. Pada Sekolah Islam Terpadu terdapat proses internalisasi nilai-nilai pendidikan Islam yang menyeluruh pada kurikulumnya untuk membentuk sikap religius siswa yang Islami. ${ }^{10}$

Sekolah Islam Terpadu pada merupakan sekolah atau madrasah yang mengimplementasikan konsep pendidikan Islam berlandaskan $\mathrm{Al}$ Qur'an dan Al Hadits. Sekolah Islam Terpadu ialah Sekolah Islam yang diselenggarakan dengan memadukan secara Integratif nilai dan ajaran Islam dalam sebuah kurikulum dengan pendekatan pembelajaran yang efektif dan pelibatan yang optimal serta koperatif antara guru, orang tua, serta masyarakat untuk membina karakter dan kompetensi peserta didik. ${ }^{11}$ Salah satu Sekolah Islam Terpadu yang menjadi anggota JSIT di surabaya adalah SDIT Ghilmani yang berlokasi di Jalan Ketintang Barat I, Surabaya Selatan.

SDIT Ghilmani menerapkan pendekatan penyelenggaraan pendidikan yang terpadu, yakni dengan memadukan pendidikan umum dan pendidikan agama menjadi sebuah kurikulum yang utuh. Jumlah siswa di SDIT Ghilmani meningkat dari tahun ke tahun. Hal ini diduga terjadi karena meningkatnya kebutuhan akan sekolah Islam yang dapat membentengi siswa dalam era globalisasi ini dan SDIT Ghilmani telah berhasil mencetak generasi muslim yang memiliki sikap religius terpuji. Untuk membuktikan hal tersebut maka pelu dilakukan kajian pada SDIT Ghilmani.

Berdasarkan uraian di atas, penelitian ini dilakukan untuk mendeskripsikan kurikulum SDIT Ghilmani dan proses internalisasi nilainilai pendidikan Islam dalam membentuk sikap religius siswa, serta mengetahui hubungan antara internalisasi nilai-nilai pendidikan Islam dengan pembentukan sikap religius siswa. Hasil penelitian ini diharapkan dapat dijadikan acuan khususnya pada SDIT Ghilmani untuk melakukan

10 Ahmad Islami Jamil, "Pesat, Perkembangan Sekolah Islam Terpadu". Artikel internet di republika.co.id. Diakses 3 September 2019.

11 JSIT, "Pengertian Sekolah Islam Terpadu". Artikel internet pada https://jsitindonesia.com/sample-page/pengertian-sekolah-islam-terpadu/. Diakses tanggal 3 September 2019. 
peningkatan kualitas secara terus menerus agar dapat mencetak generasi yang rabbani, berprestasi dan mandiri.

\section{Kurikulum SDIT Ghilmani Surabaya}

SDIT Ghilmani mempunyai visi "Terbentuknya generasi robbani yang berprestasi dan mandiri" dan misi yaitu "menyelenggarakan pendidikan dasar yang menjamin semua siswa mampu berprestasi terbaik dalam bidang akademik dan non akademik serta mandiri melalui pendidikan dan pengelolaan sekolah berkualitas". Selain menetapkan visi misi, SDIT Ghilmani juga menetapkan indikator tercapainya visi dan misi tersebut. Indikator tersebut digunakan SDIT Ghilmani sebagai acuan dalam evaluasi visi misi, apakah visi dan misi telah tercapai atau belum. Jika belum maka SDIT Ghilmani harus melakukan tindak lanjut atau perbaikan. Berikut ini adalah 11 indikator tercapainya visi SDIT Ghilmani Surabaya antara lain: 1) Mampu membaca Al Qur'an dengan baik dan benar; 2) Mampu melakukan wudhu dan sholat berjamaah sesuai dengan hadits dan kesadaran sendiri; 3) Bersikap sopan santun terhadap orang tua, guru, teman dan orang lain; 4) Memiliki kesadaran untuk bersedekah; 5) Memiliki budaya disiplin dan bertanggungjawab; 6) Memiliki budaya membaca; 7) Mempunyai prestasi di bidang akademik dan non akademik; 8) Memiliki budaya bersih, rapi dan peduli lingkungan; 9) Mampu menuntaskan semua mata pelajaran; 10) Mampu berkompetisi masuk ke sekolah yang diinginkan; 11) Memiliki jiwa kewirausahaan. ${ }^{12}$

Selain indikator visi, SDIT Ghilmani juga telah menetapkan indikator tercapainya misi, antara lain: 1) Melaksanakan dan mengembangkan kurikulumm dengan maksimal; 2) Meningkatkan mutu proses belajar mengajar; 3) Menjadikan siswa siswi memiliki ahlakul karimah (akhlak yang mulia) dan kecakapan hidup/life skill dengan berpedoman pada Al Qur'an dan Hadits: 4) Menjalankan sistem pendidikan dan pengajaran yang bermutu; 5) Meningkatkan kualitas sumber daya manusia yang beretika dan berprestasi; 6) Mengembangkan sarana dan prasarana untuk meningkatkan pelayanan yang prima kepada warga sekolah; 7) Merencanakan dan melaporkan pembiayaan secara akuntabel.

12 Berdasarkan 11 indikator dari visi tersebut, SDIT Ghilmani Surabaya melakukan internalisasi nilai-nilai pendidikan Islam untuk membentuk sikap religius siswanya menjadi generasi yang robbani yang berprestasi dan mandiri. Dengan visi tersebut, lembaga ini menginternalisasikan nilai-nilai pendidikan Islam baik dalam proses pembelajaran ataupun dalam hal manajemen pendidikan.

El-Banat Vol. 9. No.2 (2019) 201 
Struktur kurikulum satuan pendidikan SDIT Ghilmani terdiri atas kompetensi inti dan kompetensi tambahan. Dalam usaha mencapai standar kompetensi lulusan sebagaimana telah ditetapkan pada tingkat kompetensi pendidikan dasar, maka SDIT Ghilmani juga menetapkan kompetensi inti yang harus dicapai lulusan. Tingkat kompetensi merupakan kriteria capaian kompetensi bersifat umum yang harus dipenuhi oleh peserta didik dalam rangka mencapai Standar Kompetensi Lulusan. Dimensi kompetensi lulusan jenjang Sekolah Dasar dapat dilihat pada Tabel 1.

Tabel 1. Dimensi Kompetensi Lulusan Jenjang Sekolah Dasar

\begin{tabular}{|c|c|c|}
\hline Dimensi Sikap & $\begin{array}{c}\text { Dimensi } \\
\text { Pengetahuan } \\
\text { (Kognitif) }\end{array}$ & $\begin{array}{c}\text { Dimensi } \\
\text { Keterampilan } \\
\text { (Psikomotorik) }\end{array}$ \\
\hline $\begin{array}{l}\text { Memiliki perilaku yang } \\
\text { mencerminkan sikap: } \\
\text { 1. Beriman dan } \\
\text { bertaqwa kepada } \\
\text { Tuhan YME } \\
\text { 2. Berkarakter, jujur, } \\
\text { dan peduli } \\
\text { 3. Bertanggungjawab } \\
\text { 4. Pembelajar sejati } \\
\text { sepanjang hayat, } \\
\text { sehat jasmani dan } \\
\text { rohani sesuai } \\
\text { dengan } \\
\text { perkembangan anak } \\
\text { di lingkungan } \\
\text { keluarga, sekolah, } \\
\text { masyarakat dan } \\
\text { lingkungan alam } \\
\text { sekitar, bangsa, dan } \\
\text { negara. }\end{array}$ & $\begin{array}{l}\text { Memiliki } \\
\text { pengetahuan faktual, } \\
\text { konseptual, } \\
\text { prosedural, dan } \\
\text { metakognitif pada } \\
\text { tingkat dasar } \\
\text { berkenaan dengan: } \\
\text { 1. ilmu pengetahuan } \\
\text { 2. teknologi } \\
\text { 3. seni, dan } \\
\text { 4. budaya } \\
\text { Mampu mengaitkan } \\
\text { pengetahuan di atas } \\
\text { dalam konteks diri } \\
\text { sendiri, keluarga, } \\
\text { sekolah, masyarakat } \\
\text { dan lingkungan alam } \\
\text { sekitar, bangsa, dan } \\
\text { negara. }\end{array}$ & $\begin{array}{l}\text { Memiliki keterampilan } \\
\text { berpikir dan bertindak: } \\
\text { 1. Kreatif, } \\
\text { 2. Produktif, } \\
\text { 3. Kritis, } \\
\text { 4. Mandiri, } \\
\text { 5. Kolaboratif, dan } \\
\text { 6. Komunikatif } \\
\text { melalui pendekatan } \\
\text { ilmiah sesuai dengan } \\
\text { tahap perkembangan } \\
\text { anak yang relevan } \\
\text { dengan tugas yang } \\
\text { diberikan }\end{array}$ \\
\hline
\end{tabular}

Kompetensi inti dikembangkan untuk mencapai kompetensi lulusan. Kompetensi inti merupakan gambaran secara kategorial mengenai kompetensi dalam aspek sikap, pengetahuan dan keterampilan 
yang harus dipelajari peserta didik untuk suatu jenjang sekolah, kelas dan mata pelajaran. ${ }^{13}$

Dari penjelasan waka kurikulum di atas, dapat dipahami bahwa kompetensi inti dirancang seiring dengan meningkatnya usia peserta didik pada kelas tertentu. Melalui kompetensi inti integrasi vertikal berbagai kompetensi dasar pada kelas yang berbeda dapat dijaga. Rumusan komptensi inti menggunakan notasi sebagai berikut: 1) Kompetensi inti-1 (KI-1) untuk kompetensi inti sikap spiritual, 2) Kompetensi inti-2 (KI-2) untuk kompetensi inti sikap sosial, 3) Kompetensi inti-3 (KI-3) untuk kompetensi inti pengetahuan, dan 4) Kompetensi inti-4 (KI-4) untuk kompetensi inti keterampilan. Kompetensi inti-1 (KI-1) dan Kompetensi inti-2 (KI-2) secara tertulis dikembangkan pada mata pelajaran Pendidikan Agama Islam dan PPKn. Rumusan KI-1 dan KI-2 pada SDIT Ghilmani secara detil tercantum pada Tabel 2.

Tabel 2. Kompetensi inti jenjang Sekolah Dasar

\begin{tabular}{|c|c|}
\hline $\begin{array}{l}\text { Kompetensi } \\
\text { Inti }\end{array}$ & Deskripsi Kompetensi \\
\hline $\begin{array}{l}\text { Sikap } \\
\text { Spiritual }\end{array}$ & $\begin{array}{l}\text { 1. Menerima, menjalankan dan menghargai ajaran } \\
\text { agama yang dianutnya }\end{array}$ \\
\hline Sikap sosial & $\begin{array}{l}\text { 2. Menunjukkan perilaku: } \\
\text { a. jujur, } \\
\text { b. disiplin, } \\
\text { c. santun, } \\
\text { d. percaya diri, } \\
\text { e. peduli, dan } \\
\text { f. bertanggungjawab dalam dimensi keluarga, } \\
\text { teman, guru, tetangga dan negara }\end{array}$ \\
\hline Pengetahuan & $\begin{array}{l}\text { 3. Memahami pengetahuan faktual, konseptual, } \\
\text { prosedural, dan metakognitif pada tingkat dasar } \\
\text { dengan cara: } \\
\text { a. mengamati, } \\
\text { b. menanya, dan } \\
\text { c. mencoba } \\
\text { berdasarkan rasa ingin tahu tentang dirinya, } \\
\text { makhluk ciptaan Tuhan dan kegiatannya, dan }\end{array}$ \\
\hline
\end{tabular}

${ }^{13}$ Dalam kurikulum yang diterapkan di SDIT Ghilmani, kompetensi inti menjadi unsur organisatoris (organizing element) Kompetensi Dasar (KD). Sehingga seluruh Kompetensi Dasar yang dikembangkan dalam proses pembelajaran dirancang untuk mencapai kompetensi inti. 


\begin{tabular}{|c|c|c|}
\hline & & $\begin{array}{l}\text { benda-benda yang dijumpainya di rumah, sekolah } \\
\text { dan tempat bermain. }\end{array}$ \\
\hline Keterampilan & & $\begin{array}{l}\text { Menunjukkan keterampilan berfikir dan bertindak: } \\
\text { a. kreatif, } \\
\text { b. produktif, } \\
\text { c. kritis, } \\
\text { d. mandiri, } \\
\text { e. kolaboratif, dan } \\
\text { f. komunikatif } \\
\text { dalam bahasa yang jelas, sistematis, logis dan } \\
\text { kritis, dalam karya yang estetis, dalam gerakan } \\
\text { yang mencerminkan anak sehat, dan tindakan yang } \\
\text { mencerminkan perilaku anak sesuai dengan tahap } \\
\text { perkembangannya. }\end{array}$ \\
\hline
\end{tabular}

Pengembangan sikap sipritual dan sikap sosial di SDIT Ghilmani Surabaya dikembangkan melalui muatan lokal sekolah dan pembiasaan sehari-hari. Muatan lokal SDIT Ghilmani meliputi Bahasa Arab, Al Qur'an, Tahfidz, Aqidatul Awwam, dan Sulam Taufiq. Pembiasaan sehari-hari yang dikembangkan untuk sikap sosial di SDIT Ghilmaani yaitu Jumat berkah, sholat dhuha, dan kaleng taubat. Untuk mencapai visi misi yang telah ditetapkan, SDIT Ghilmani merancang kurikulum yang memadukan antara pendidikan umum dan pendidikan agama. ${ }^{14}$

Tujuan kurikulum di SDIT Ghilmani Surabaya terdiri atas empat kompetensi, yaitu: 1) kompetensi sikap spiritual, 2) sikap sosial, 3) pengetahuan, dan 4) keterampilan. Kompetensi tersebut dicapai melalui proses pembelajaran intrakurikuler, kokurikuler, dan/atau ekstrakurikuler. Kompetensi sikap spiritual dan kompetensi sikap sosial dapat dicapai dengan cara pembelajaran tidak langsung (indirect teaching), meliputi keteladanan, dan pembiasaan serta budaya sekolah dengan memperhatikan karakteristik mata pelajaran serta kebutuhan dan kondisi siswa-siswi. Penumbuhan dan pengembangan kompetensi sikap dapat dilakukan sepanjang proses pembelajaran berlangsung, kemudian digunakan sebagai pertimbangan oleh guru untuk mengembangkan karakter peserta didik lebih lanjut.

${ }^{14}$ Sistem pendidikan SDIT Ghilmani merupakan kombinasi sistem pembelajaran model umum, pesantren dan madrasah. Kurikulumnya didesain dengan memuat konsep 3 kurikulum, yaitu kurikulum Kementerian Pendidikan Nasional, Kurikulum Kementerian Agama dan kurikulum lokal SDIT Ghilmani Surabaya. 
Tabel 3. Struktur Program Pembelajaran dan Alokasi Waktu SDIT Ghilmani Surabaya

\begin{tabular}{|c|c|c|c|c|c|c|c|}
\hline \multirow{3}{*}{ No } & \multirow{3}{*}{ Mata Pelajaran } & \multirow{2}{*}{\multicolumn{6}{|c|}{$\begin{array}{c}\text { Alokasi waktu per Minggu } \\
(\text { jam })\end{array}$}} \\
\hline & & & & & & & \\
\hline & & $\mathbf{I}$ & II & III & IV & $\mathbf{V}$ & VI \\
\hline \multicolumn{8}{|c|}{ KELOMPOK A } \\
\hline 1. & $\begin{array}{l}\text { Pendidikan Agama dan Budi } \\
\text { Pekerti }\end{array}$ & 4 & 4 & 4 & 4 & 3 & 3 \\
\hline 2. & $\begin{array}{l}\text { Pendidikan Panacasila \& } \\
\text { Kewarganegaraan }\end{array}$ & 5 & 5 & 6 & 5 & 5 & 5 \\
\hline 3. & Bahasa Indonesia & 8 & 9 & 10 & 7 & 7 & 7 \\
\hline 4. & Matematika & 5 & 6 & 6 & 6 & 6 & 6 \\
\hline 5. & Ilmu Pengetahuan Alam & & & & 3 & 3 & 3 \\
\hline 6. & Ilmu Pengetahuan Sosial & & & & 3 & 3 & 3 \\
\hline \multicolumn{8}{|c|}{ KELOMPOK B } \\
\hline 7. & Seni Budaya dan Prakarya & 4 & 4 & 4 & 5 & 5 & 5 \\
\hline 8. & $\begin{array}{l}\text { Pendidikan Jasamani } \\
\text { Olahraga \& Kesehatan }\end{array}$ & 4 & 4 & 4 & 4 & 4 & 4 \\
\hline 9. & Bahasa Jawa & 2 & 2 & 2 & 2 & 2 & 2 \\
\hline 10. & Bahasa Inggris & 2 & 2 & 2 & 2 & 2 & 2 \\
\hline 11. & Bahasa Arab & 2 & 2 & 2 & 2 & 2 & 2 \\
\hline \multicolumn{2}{|c|}{ Jumlah alokasi waktu per minggu } & 36 & $\begin{array}{l}3 \\
8\end{array}$ & 40 & 42 & $\begin{array}{l}4 \\
2\end{array}$ & 42 \\
\hline
\end{tabular}

Mata pelajaran Kelompok A adalah mata pelajaran yang kontennya dikembangkan oleh Kementerian Pendidikan dan Kebudayaan (Kementerian Pendidikan Nasional). Sementara, mata pelajaran Kelompok B, terdiri dari mata pelajaran Seni Budaya dan Prakarya serta Pendidikan Jasmani, Olahraga dan Kesehatan merupakan kelompok mata pelajaran yang kontennya dikembangkan oleh Kemendikbud, dilengkapi oleh konten lokal yang dikembangkan oleh pemerintah daerah yaitu Bahasa Jawa dan Bahasa Inggris. Sedangkan mata pelajaran khas dari SDIT Ghilmani adalah Bahasa Arab yang kontennya dikembangkan dari Kementerian Agama.

Selain program pembelajaran di atas, SDIT Ghilmani Surabaya juga melaksanakan pembelajaran ekstrakurikuler. Ekstrakurikuler adalah 
kegiatan pendidikan yang merupakan perluasan dari kurikulum SDIT Ghilmani dan dibawah bimbingan Sekolah. Kegiatan ini dilakukan di luar jam sekolah, yang ditujukan supaya siswa-siswi SDIT Ghilmani dapat mengembangkan bakat, kepribadian, dan kemampuannya di berbagai bidang di luar bidang akademik. Kegiatan ekstrakurikuler SDIT Ghilmani dikelompokkan menjadi 3 jenis, antara lain: 1) Ekstrakurikuler wajib nasional, yaitu Pramuka mulai kelas I sampai VI.; 2) Ekstrakurikuler wajib SDIT Ghilmani yaitu, ekstrakurikuler Komputer; 3) Ekstrakurikuler pilihan, antara lain: olahraga prestasi, yaitu: Pertama, sepak bola, taekwondo, panahan, silat, dan futsal. Kedua, kesenian, ada 3, yaitu: a) seni musik: samroh, pianika, dan banjari, 2) Seni rupa: menggambar, 3) Seni sastra: Qiro'ah, jurnalistik, dokter kecil, club sains, english club, dan math club.

Dalam era globalisasi saat ini, pendidikan wajib bergeser ke arah pendidikan yang berwawasan global. Pendidikan tidak boleh mengabaikan proses globalisasi yang akan mewujudkan masyarakat global ini. Dalam menuju era globalisasi, SDIT Ghilmani telah melakukan reformasi dalam proses pendidikan dengan menciptakan sistem pendidikan yang lebih fleksibel dan komprehensif, supaya para lulusan dapat terlibat secara aktif dan efektif dalam kehidupan masyarakat global demokratis. Berikut penjelasan kepala SDIT Ghilmani Surabaya, Ibu Candra Murni berikut ini:

“..Pendidikan berwawasan global dirancang sedemikian rupa sehingga memungkinkan para peserta didik mengembangkan potensi yang dimiliki secara alamai dan dan kreatif dalam suasana penuh kebebasan, kebersamaan dan tanggungjawab..."15

Dari hasil wawancara di atas, penulis dapat menganalisis bahwa tujuan pendidikan berwawasan global di SDIT Ghilmani Surabaya adalah agar dapat menghasilkan lulusan yang dapat memahami masyarakatnya dengan segala faktor yang dapat mendukung mencapai sukses ataupun penghalang yang menyebabkan kegagalan dalam kehidupan bermasyarakat, dengan terus memotivasi peserta didik agar dengan sukarela: 1) Mempelajari sosial, budaya, politik, dan ekonomi bangsa lain dengan titik berat memahami adanya saling ketergantungan; 2) Mempelajari berbagai bidang ilmu pengetahuan untuk digunakan sesuai dengan kebutuhan lingkungan setempat; 3) Mengembangkan berbagai kemampuan dan keterampilan untuk bekerjasama guna mewujudkan kehidupan masyarakat dunia yang lebih sejahtera. Keunggulan global yang dikembangkan di SDIT Ghilmani dalam upaya menuju pendidikan

15 Candra Murni, Wawancara, Surabaya, 11 September 2019. 
berwawasan global adalah: muatan lokal Bahasa Inggris, ekstrakurikuler komputer dan hafidz Qur'an minimal 2 juz

\section{Nilai-nilai Pendidikan Islam sebagai Fondasi Sikap Religius Siswa}

Pendidikan agama Islam secara umum lebih berkonsentrasi pada persoalan teoritis keagamaan yang bersifat kognitif dan kurang terkonsentrasi pada persoalan bagaimana mengubah pengetahuan agama yang kognitif menjadi bermakna dan bernilai yang perlu diinternalisasikan dalam diri peserta didik lewat berbagai cara, media, maupun forum. ${ }^{16}$

Internalisasi adalah upaya untuk menghayati dan mendalami nilai, supaya tertanam dalam diri tiap manusia, ${ }^{17}$ dengan teknik pendidikannya dilakukan melalui peneladanan, pembiasaan, penegakan aturan, dan pemotivasian. ${ }^{18}$ Untuk melakukan internalisasi nilai-nilai pendidikan Islam, dapat dilakukan melalui lima macam strategi meliputi: keteladanan (modeling strategy), strategi pembiasaan, ibrah dan amtsal, pemberian nasehat, targhib wa tarhib (pemberian janji dan ancaman), dan strategi kedisiplinan. ${ }^{19}$

Secara teori, proses internalisasi nilai dapat dilakukan melalui tiga tahapan yaitu: Pertama, tahap transformasi, internalisasi nilai dilakukan dengan menyampaikan materi fisik melalui pengajaran di kelas, ceramah pada peserta didik agar mereka tahu dan paham nilai-nilai yang baik dan buruk dalam ajaran agama Islam. Tahap transformasi disebut juga dengan proses pemahaman atau menumbuhkan tingkat afektif peserta didik tentang nilai-nilai pendidikan Islam. Kedua disebut tahap transaksi, yaitu internalisasi nilai dilakukan melalui komunikasi dua arah (timbal balik) yakni informasi nilai yang diperoleh dan dipahami peserta didik melalui contoh perbuatan yang dicontohkan guru, hingga para peserta didik juga dapat merespon nilai yang sama. Tahap ini merupakan tahap penghayatan yang bermuara pada peningkatan kognitif siswa mengenai nilai-nilai pendidikan Islam. Ketiga, tahap transinternalisasi yaitu internalisasi tidak hanya dilakukan dengan komunikasi verbal tapi juga sikap mental dan kepribadian. Jadi pada tahap ini komunikasi kepribadian yang berperan

16 Abdul Majid, Belajar dan Pembelajaran Pendidikan Agama Islam (Bandung: Remaja Rosdakarya, 2014), 10.

17 E. Mulyasa, Manajemen Pendidikan Karakter (Bandung: Rosda Karya. 2011), 197.

${ }^{18}$ Ahmad Tafsir, Ilmu Pendidikan Islami (Bandung: Rosda Karya, 2010), 51.

19 Muhammad Munif, "Strategi Internalisasi Nilai-nilai PAI dalam Membentuk Karakter Siswa", Edureligia, Vol. 1 No. 1 (2017): 1 - 12.

El-Banat Vol. 9. No.2 (2019) 207 
secara aktif. ${ }^{20}$ Pendapat Muhammad Alim tersebut sesuai dengan data yang penulis peroleh dari wawancara dengan salah seorang guru Pendidikan Agama Islam (PAI) di SDIT Ghilmani Surabaya, Ibu Nurul Furoidatur Rohmah, berikut ini:

“...SDIT Ghilmani Surabaya menyadari bahwa proses internalisasi nilainilai pendidikan Islam untuk membentuk sikap religius peserta didik tidak dapat dilakukan secara instan. Sehingga lembaga ini menerapkan beberapa strategi yang kami rancang, agar pembentukan sikap religius siswa yang robbani benar-benar tercapai..."21

Penjelasan Ibu Nurul Furoidatur Rohmah di atas diperkuat oleh penjelasan Bapak Zainal Arifin berikut ini:

"..Empat dari lima strategi yang dikembangkan secara teoritis dipilih oleh SDIT Ghilmani untuk internalisasi nilai-nilai pendidikan Islam pada peserta didiknya. Empat strategi tersebut yaitu: strategi pembiasaan, strategi keteladanan (modelling), strategi kedisiplinan dan strategi pemberian nasehat atau ajakan. Diharapkan melalui strategi ini, sikap religius siswa dapat terbentuk sesuai visi SDIT Ghilmani yaitu mencetak generasi robbani yang mandiri dan berprestasi.." 22

Berdasarkan hasil wawancara di atas, maka penulis dapat mengambil benang merah, bahwa proses internalisasi nilai-nilai pendidikan Islam di SDIT Ghilmani dilakukan melalui 3 jenis kegiatan, yaitu: 1) kegiatan rutin, 2) kegiatan spontan, dan 3) kegiatan keteladanan. Masing-masing kegiatan tersebut dijabarkan sebagai berikut: Pertama, Kegiatan-kegiatan rutin yang dilaksanakan di SDIT Ghilmani Surabaya yang berhubungan dengan nilai-nilai pendidikan Islam, antara lain kegiatan ibadah atau do'a. Kegiatan ini bertujuan untuk membina dan mengembangkan penghayatan dan pengamalan iman dan taqwa kepada Allah Yang Maha Esa sesuai perkembangan masing-masing peserta didik. Pelaksanaan pembelajaran: 1) Sebelum Proses Belajar Mengajar (PBM) berlangsung semua siswa melaksanakan sholat dhuha di kelas masing-masing. Untuk hari Jum'at sholat dhuha dilaksanakan secara berjamaah di masjid untuk siswa laki-laki, dan di aula untuk siswa perempuan; 2) Peserta didik kelas tiga melaksanakan sholat Jum'at di Taklim, sedangkan untuk peserta didik kelas $4-6$ di Masjid Baitussyakur; 3) Doa bersama diikuti oleh semua peserta didik pada saat

${ }^{20}$ Muhammad Alim, Pendidikan Agama Islam Upaya Pembentukan Pemikiran dan Kepribadian Muslim (Bandung: Remaja Rosdakarya, 2006), 14.

${ }^{21}$ Nurul Furoidatur Rohmah, Wawancara, Surabaya, 19 September 2019.

22 Zainal Arifin, Wawancara, Surabaya, 21 September 2019. 
awal dan akhir kegiatan pembelajaran; 4) Sholat dhuhur berjamaah untuk peserta didik kelas $1-3$, pelaksanaan sholat dhuhur di kelas masingmasing dengan pembagian piket petugas imam dan adzan. Untuk peserta didik kelas $4-6$, pelaksanaan sholat dhuhur di aula dengan imam seorang ustadz. Selain itu, sholat ashar juga dilakukan berjamaah di sekolah untuk peserta didik kelas $3-6$; 5) Setelah doa pagi, peserta didik dianjurkan untuk infaq dengan tujuan menambah keberkahan ilmu yang dicarinya; 6) Makan siang bersama yang dilaksanakan ketika jam istirahat kedua, masing-masing petugas piket makan yang telah dibentuk mengambil perlengkapan makan siang. Kemudian mereka antri untuk mengambil jatah makan siang. Petugas piket makan siang akan mengembalikan lagi perlengkapan makan siang ke dapur; 7) Setelah makan siang, petugas piket kebersihan bertugas membersihkan kelas, mulai dari menyapu, menyulak, mengepel, sampai membuang sampah yang ada di kelas ke tempat sampah yang berada di luar kelas. ${ }^{23}$

Kedua, nilai-nilai pendidikan Islam juga dimasukkan dalam kegiatan spontan di SDIT Ghilmani Surabaya. Kegiatan pengembangan diri secara spontan berupa kebiasaan sopan santun dan sikap terpuji. Kegiatan ini dilaksanakan bersama-sama dengan semua kegiatan di sekolah setiap saat berupa pembiasaan saling tegur sapa dan saling hormat kepada semua warga dan tamu sekolah dengan mengucap salam sesuai norma yang berlaku. Di samping itu, peserta didik perlu dipandu untuk memiliki kebiasaan hidup tertib, bersih, sehat dan aman dengan cara antara lain: 1) Selalu tertib dan disiplin dalam belajar dan memanfaatkan waktu; 2) Membuang sampah pada tempatnya, karena kebersihan adalah sebagian dari iman; 3) Membiasakan diri berpola hidup sehat; 4) Tidak merokok dan tidak mengkonsumsi bahan/obat terlarang; 5) Ikut aktif berpartisipasi dalam pencegahan terhadap gangguan keamanan; 6) Membiasakan ijin ketika keluar dan masuk ruangan; 7) Selalu antre dalam segala hall (mengambil makan, membeli kue, ke kamar mandi, wudhu, dan lain-lain); 7) Menolong atau peduli pada teman yang membutuhkan; 8) Tawadhu' terhadap guru (membantu membawakan barang bawaan guru sampai ke tempatnya); 9) Khotmil Qur'an untuk meningkatkan ketaqwaan kepada Allah kepada Allah SWT dan melancarkan bacaan Al Qur'an santri; 10) Sholat Ghoib jika ada Habib atau ulama yang meninggal dunia

Ketiga, keteladanan. Selain melalui kegiatan rutin dan kegiatan spontan, internalisasi nilai-nilai pendidikan Islam juga dilakukan dalam kegiatan keteladanan. Kegiatan keteladanan yang dikembangkan di SDIT

${ }^{23}$ Beberapa kegiatan rutin tersebut dinilai oleh guru Pendidikan Agama Islam, di mana nilai kegiatan ini termasuk dalam nilai sikap spiritual. 
Ghilmani adalah perilaku sehari-hari yang dapat dicontoh. Kegiatan ini terintegrasi dalam semua kegiatan sekolah setiap saat yang merupakan implementasi dari tata krama dan budi pekerti yang diwujudkan antara lain dengan: 1) Selalu berpikiran positif terhadap sesame; 2) Selalu berusaha bersikap, bertindak, dan bertutur secara santun; 3) Selalu bersikap jujur dan terbuka; 4) Selalu bersikap ramah penuh keakraban menurut batas norma pergaulan; 5) Selalu menggunakan bahasa yang baik dan cermat: 6) Selalu berusaha untuk tidak bersikap over actingdalam pergaulan; 7) Selalu berusaha menambah wawasan dan pengetahuan melalui kegemaran membaca.

Berdasarkan kegiatan-kegiatan yang telah dilakukan, guru SDIT Ghilmani melakukan penilaian terhadap sikap religius peserta didiknya, sesuai dengan aspek-aspek penilaian dalam Tabel 4. Nilai minimum untuk pembiasaan, budaya dan keteladanan adalah B. ${ }^{24}$

Tabel 4. Aspek Penilaian Non Akademis

(Pembiasaan, Budaya, Dan Keteladanan)

\begin{tabular}{|c|l|l|l|l|l|l|l|}
\hline No. & Aspek Penilaian & \multicolumn{5}{|c|}{ Nilai } & Ket \\
\cline { 2 - 7 } & 1. PEMBIASAAN & & & & & & \\
\hline 1. & $\begin{array}{l}\text { Hormat dan patuh kepada } \\
\text { orang tua, guru dan semua } \\
\text { warga sekolah }\end{array}$ & & & & & \\
\hline 2. & $\begin{array}{l}\text { Berperilaku ramah, sopan } \\
\text { santun, tanggung jawab, } \\
\text { mandiri, peduli pada } \\
\text { sesama dan peduli pada } \\
\text { pelestarian dan kerusakan } \\
\text { lingkungan, dan berlapang }\end{array}$ & & & & & \\
\hline 3. & $\begin{array}{l}\text { Senantiasa ba baru, } \\
\text { dada }\end{array}$ & & & & & \\
\hline 4. & $\begin{array}{l}\text { Menghargai dari } \\
\text { karyawan, dan teman }\end{array}$ & & & & & \\
\hline 5. & $\begin{array}{l}\text { Menjauhkan diri dari } \\
\text { segala sengketa dan } \\
\text { perbuatan tercela }\end{array}$ & & & & \\
\hline
\end{tabular}

${ }^{24}$ Para guru akan menjelaskan penilaian non akademis siswa terlebih dahulu kepada wali siswa. Dengan penjelasan tersebut diharapkan wali siswa juga mendidik putra-putri mereka selama di rumah sesuai dengan nilai-nilai pendidikan Islam yang telah diajarkan di sekolah. Hal ini bertujuan agar peserta didik menjadi terbiasa, memiliki budaya agamis dan memiliki sikap keteladanan. 


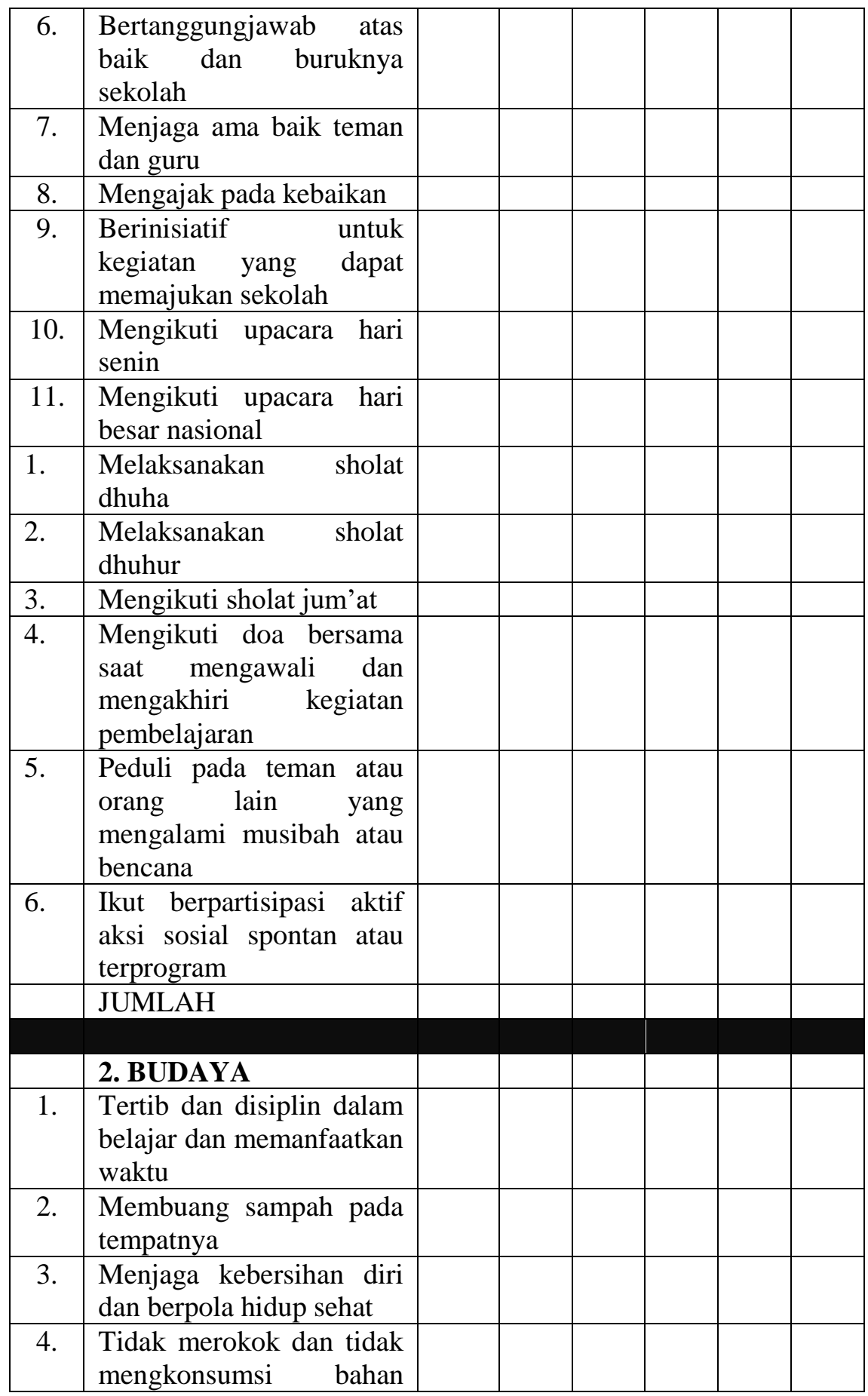

El-Banat Vol. 9. No.2 (2019) 211 


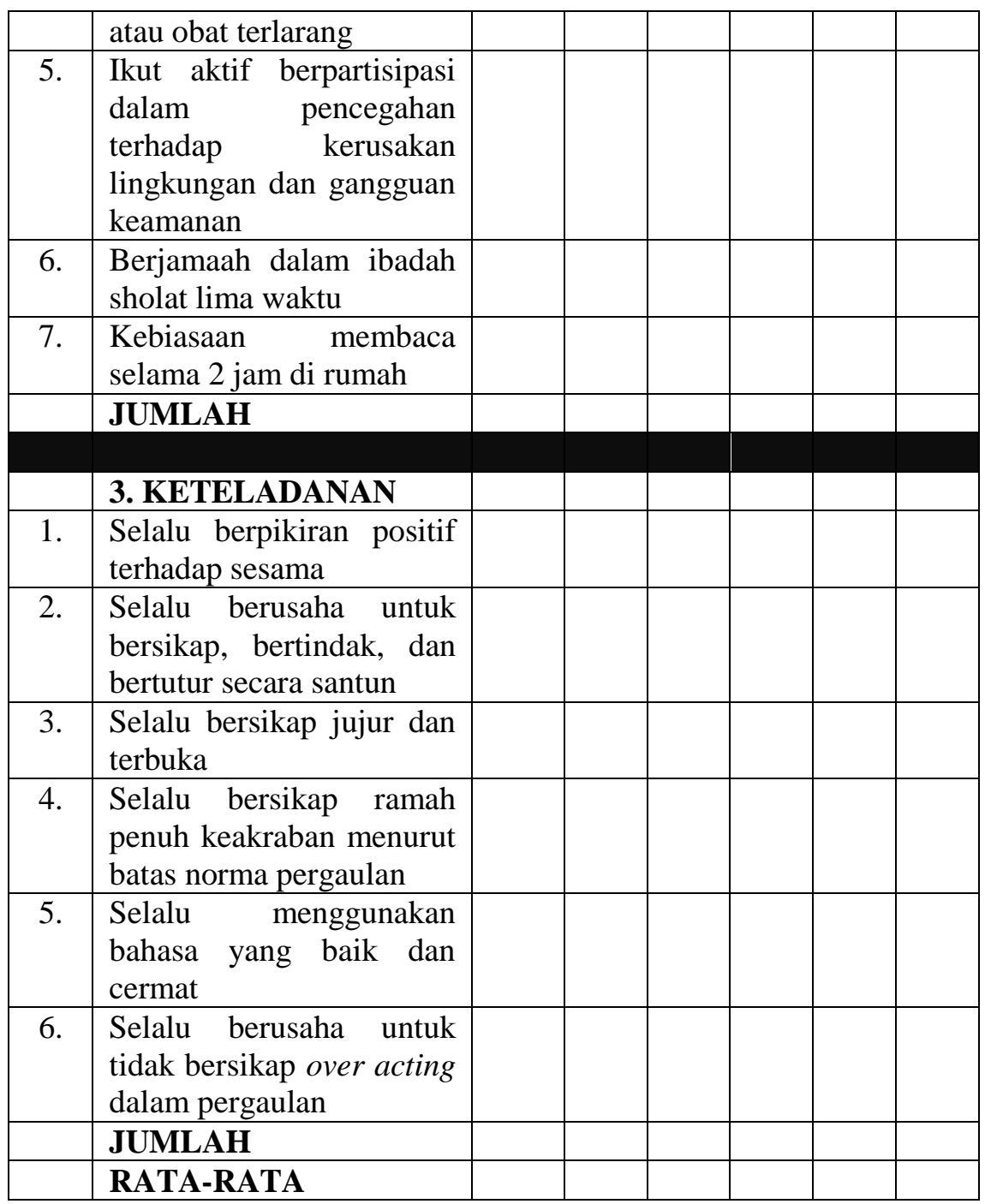

Konversi nilai rata-rata:
A : Sangat baik $=4,5-5,0$
$\mathrm{B}:$ Baik $\quad=3,5-4,4$
$\mathrm{C}:$ Cukup $\quad=2,5-3,4$
$\mathrm{D}:$ Kurang $\quad=1,5-2,4$
$\mathrm{E}:$ Kurang sekali $=0,5-1,4$

Dari tabel di atas, penulis melakukan wawancara dengan waka kurikulum SDIT Ghilmani Surabaya untuk memperolah gambaran yang lebih jelas. Dalam keteranga Ibu Irawati, memaparkan: 
“..Dalam proses penilaian sikap religius siswa, harus melibatkan semua guru kelas, guru mata pelajaran, para pembina serta siswa yang lain. Pelaksanaan perkembangan sikap religius siswa dicatat oleh guru dan digunakan untuk memberi rekomendasi kepada guru kelas..."25

Aspek Nilai-nilai pendidikan Islam yang ditanamkan, ditinjau dari: Pertama, pola sikap religius kepada Allah SWT. Nilai-nilai pendidikan Islam yang ditanam SDIT Ghilmani ditinjau dari pola sikap religius kepada Allah SWT antara lain aspek nilai aqidah, ibadah dan akhlak. Proses penanaman nilai-nilai yang berhubungan dengan sikap religius pada Allah SWT diberikan melalui mata pelajaran Pendidikan Agama Islam yang didalamnya terdapat aspek Aqidah, akhlak, fiqh serta Alqur'an dan Hadist. Setiap hari nilai-ini ditanamkan secara formal pada mata pelajaran pendidikan agama islam saja, namun juga diintegrasikan pada seluruh mata pelajaran yang ada. Setiap memulai pelajaran, bapak/ibu guru memimpin untuk berdoa bersama terlebih dahulu dan menanyakan bagaimana ibadah sholat mereka, apakah tetap dilaksanakan rutin atau tidak. Di akhir pembelajaran, diakhir dengan doa. Selain itu Bapak/Ibu guru juga mengingatkan kembali untuk selalu sholat lima waktu dan belajar dengan rajin. Kegiatan tersebut merupakan upaya sekolah untuk membentuk sikap religius siswa kepada Allah SWT.

"..Penanaman nilai-nilai pendidikan Islam untuk membentuk sikap religius kepada Allah juga dilakukan melalui metode pembiasaan. Kegiatan belajar siswa dimulai pukul 6.45 dengan masuk kelas dan berdoa, kecuali Senin diawali dengan Upacara terlebih dahulu dan berdoa,dilanjutkan sholat dhuha. Selanjutnya di sela-sela jadwal pelajaran selalu ada sesi muroja'ah dan di hari senin ditambah dengan Tahfidz. Pada saat dhuhur dan ashar, para siswa dibiasakan wudhu, muroja'ah dan sholat dhuhur dan ashar berjamaah di masjid SDIT Ghilmani. Setelah sholat berjamaah, para siswa dibimbing untuk berdzikir pada Allah SWT.." 26

Kegiatan ibadah rutin yang dijelaskan oleh Ibu Nurul Furoidatur Rohmah di atas porsinya akan lebih banyak di bulan Romadhon. Kegiatan sekolah berakhir setelah siswa sholat ashar berjama'ah. Para siswa bisa langsung pulang atau pada hari tertentu dilanjutkan untuk ekstrakurikuler. Kegiatan-kegiatan tersebut telah dilakukan secara rutin untuk membentuk pola sikap religius kepada Allah SWT, dan diharapkan kegiatan sholat berjamaah secara rutin tetap dilakukan siswa di rumahnya di bawah bimbingan orang tua siswa. Keesokan harinya guru

${ }^{25}$ Irawati, Wawancara, Surabaya, 2 Oktober 2019.

${ }^{26}$ Nurul Furoidatur Rohmah, Wawancara, Surabaya, 3 Oktober 2019.

El-Banat Vol. 9. No.2 (2019) 213 
menanyakan kepada siswa bagaimana sholatnya di rumah. Dengan begitu, siswa akan terbiasa untuk terus beribadah kepada Allah SWT.

Kedua, pola perilaku kepada sesama manusia. Penanaman nilainilai pendidikan Islam berkaitan dengan sikap religius kepada sesama manusia di SDIT Ghilmani terlihat pada materi Pendidikan Agama Islam khususnya Aqidah dan akhlak. Pada beberapa bab di mata pelajaran tersebut, terdapat bab tentang adab dan sopan santun terhadap orang tua, guru, tetangga dan anjuran untuk saling menyayangi dan tolong menolog pada sesama manusia. Kajian tentang kepedulian sosial seperti beramal dan shodaqoh sebagai rasa syukur atas segala rizki yang telah diberikan Allah. $^{27}$

Ketiga, pola perilaku kepada alam. Penanaman nilai-nilai pendidikan Islam berkaitan dengan sikap religius kepada alam di SDIT Ghilmani terlihat pada materi Ilmu Pengetahuan Alam (IPA). Pada beberapa bab di mata pelajaran tersebut, terdapat bab tentang kebersihan dan kesehatan lingkungan, pengelolaan sampah, bagaimana memelihara lingkungan dan menjaga kelestarian alam. Selain itu, materi tersebut juga dihubungkan dengan ayat-ayat Alqur'an tentang keharusan menjaga kelestarian alam dan larangan untuk merusak alam. Para siswa dididik untuk selalu sayang pada alam dan tidak merusaknya.

Selain pada mata pelajaran IPA, penanaman nilai-nilai pendidikan Islam untuk membentuk sikap religius kepada sesama manusia juga dilakukan melalui pembiasaan, seperti piket bergantian untuk membersihkan kelas dan lingkungan sekitar kelas setiap hari, dan kerja bakti di sekolah bersama-sama dari kelas I sampai VI. Para siswa diwajibkan menjaga kebersihan kelas dan lingkungan sekolah, tidak membuang sampah sembarangan, membuang sampah organik dan non organik pada tempat sampah dan sebagainya. Proses pembiasaan tersebut diharapkan dapat membentuk pola sikap religius siswa yang baik terhadap alam.

\section{Kurikulum, Pendidikan Islam dan Sikap Religius Siswa}

SDIT Ghilmani telah melakukan berbagai upaya untuk internalisasi nilai-nilai pendidikan Islam dalam sikap religius siswa antara lain: 1) Sosialisasi visi misi dan indikator pencapaian visi misi pada siswa, guru,

27 Aspek penanaman nilai-nilai pendidikan Islam untuk membentuk sikap religius kepada sesama manusia juga dilakukan melalui pembiasaan, seperti sedekah tiap hari Jum'at, menjenguk teman yang sakit, membantu teman yang lagi kesusahan, dan lain sebagainya. Semua kegiatan tersebut dilakukan sekolah untuk membentuk siswa yang memiliki sikap religius yang baik kepada sesama manusia. 
wali kelas, dan orang tua siswa; 2) Mengkaji ulang dan mengembangkan kurikulum SDIT secara berkala; 3) Memasukkan nilai-nilai pendidikan Islam dalam semua mata pelajaran; 4) Mengembangkan metode pembelajaran bernuansa islami; 5) Pembinaan sholat berjamaah dan muraja'ah; 6) Pembiasaan sholat dhuha, berdoa sebelum dan setelah belajar; 7) Program tahfidz untuk membina siswa agar selalu cinta Alqur'an; 8) Parenting untuk mensinergikan program sekolah dan bimbingan dan didikan orang tua di rumah

“..Interaksi pembelajaran di SDIT Ghilmani antara guru, wali kelas dan siswa berinteraksi secara baik dan harmonis. Metode pembelajaran dan suasana belajar didesain bernuansa islami, diawali dengan berdoa, muroja'ah, sholat berjamaah, dzikir dan diakhiri dengan doa bersama sebelum pulang sekolah. Azas kasih sayang dan dan kebersamaan antara guru dengan murid, dan antar sesama murid juga dikembangkan disini sehingga timbul suasana belajar yang kondusif dan nyaman..."28

Metode penanaman nilai-nilai pendidikan Islam dilakukan secara bertahap sesuai dengan jenjang kelasnya dan disesuaikan dengan perkembangan psikologis siswa. Di kelas I dan II, siswa diajak dan dibiasakan untuk berdoa, muroja'ah, sholat berjama'ah, dzikir, menghafal al Qur'an, dsb. Pada kelas-kelas selanjutnya, siswa diberi pengertian, kesadaran emosi bahwa kegiatan-kegiatan tersebut memang harus diterapkan demi membentuk generasi muslim yang robbani yang berkualitas dan mandiri. Setelah itu, mulai ada penegakan kedisiplinan dalam setiap kegiatan dan pemberian sanksi apabila ada siswa yang melanggar. Semua metode tersebut dilakukan demi mewujudkan visi SDIT Ghilmani yakni mencetak generasi robbani yang tercermin pada sikap religius para siswanya.

“..SDIT Ghilmani Surabaya sangat konsisten untuk menanamkan nilai pendidikan Islam dalam segala kegiatan siswa di sekolah, baik kegiatan pengajaran, kegiatan intrakurikuler maupun ekstrakurikuler. Hal ini menunjukkan komitmen kami dalam membangun generasi islami di Surabaya ini... ${ }^{29}$

Metode penanaman dilakukan secara bertahap mulai dari peserta didik kelas rendah yaitu dengan ajakan dan bujukan serta pembiasaan. Setelah itu di kelas menengah (kelas 3 dan 4), peserta didik diberi pemahaman, penumbuhan kesadaran dan emosi bahwa nilai-nilai pendidikan Islam tersebut memang harus diterapkan agar mereka menjadi

${ }^{28}$ Irawati, Wawancara, Surabaya, 6 Oktober 2019.

${ }^{29}$ Irawati, Wawancara, Surabaya, 9 Oktober 2019.

El-Banat Vol. 9. No.2 (2019) 215 
generasi yang Qur'ani. Untuk kelas akhir (kelas 5 dan 6), peserta didik secara umum sudah memahami pentingnya nilai pendidikan Islam tersebut, dan jika melanggar sudah dikenai sanksi.

Proses internalisasi nilai-nilai pendidikan Islam di SDIT Ghilmani Surabaya dapat dikatakan sangat baik. Hal ini terlihat dari pola sikap religius para siswa di kelas VI yang telah 5 tahun lebih belajar di SDIT Ghilmani. Jadi bisa dikatakan bahwa internalisasi nilai-nilai pendidikan Islam dapat membentuk sikap religius siswa menjadi dekat dengan Allah SWT, baik pada sesama manusia dan memperhatikan alam sekitar. Penulis menganalisis, bahwa ada perkembangan pada sikap religius siswa SDIT. Hal ini terlihat terutama pada sikap siswa kelas VI. Perkembangan sikap religius siswa kelas VI setelah menempuh pembelajaran di SDIT Ghilmani Surabaya, antara lain: Pertama, taat kepada Allah SWT, ditunjukkan dengan perubahan sikap religius yang rajin beribadah (sholat, muroja'ah, tahfidz dan dzikir) dibandingkan siswa SD pada umumnya, selalu berdoa dan bersyukur atas segala yang Allah berikan, berpuasa dan rutin bersedekah. Kedua, sikap religius siswa terhadap sesama manusia cukup baik, sopan dan santun terhadap ustadzah, orang tua dan orang lain yang lebih tua. Selain itu, saling menyayangi antar teman, dan disiplin dan berakhlak baik. Ketiga, siswa menyadari akan pentingnya menjaga kelestarian lingkungan dan tidak merusak lingkungan. Keempat, siswa memiliki kepribadian yang baik, karena di sekolah ditanamkan kejujuran, sopan santun, disiplin dan bertanggungjawab.

Meskipun metode integrasi kurikulum di SDIT Ghilmani Surabaya sangat bermanfaat dalam meningkatkan sikap religius siswa, apabila diterapkan tanpa persiapan yang baik maka dapat berakibat sebaliknya, misalnya: menurunkan iman siswa. Oleh sebab itu, guru harus hati-hati dalam model integrasi dan implementasinya dalam proses pembelajaran. Tegasnya, guru harus memperhatikan hal tersebut agar proses internalisasi nilai-nilai pendidikan Islam dapat berjalan dengan baik. Terlebih, muara dari kegiatan tersebut adalah peningkatan sikap religius siswa di SDIT Ghilmani Surabaya.

\section{Kesimpulan}

Berdasarkan hasil penelitian ini, maka dapat disimpulkan bahwa model kurikulum di SDIT Ghilmani memadukan antara kurikulum Kementerian pendidikan nasional, Kementerian Agama dan kurikulum lokal SDIT. Sekolah ini memiliki visi untuk mencetak generasi yang Robbani yang berprestasi dan mandiri. Internalisasi nilai-nilai pendidikan Islam dilakukan SDIT Ghilmani Surabaya telah dilakukan dengan baik secara formal pada setiap mata pelajaran dan secara informal pada semua 
kegiatan di sekolah. Metode penanaman nilai-nilai pendidikan Islam dilakukan secara bertahap mulai dari ajakan dan pembiasaan, penyadaran emosi dan pendisiplinan serta pemberian sanksi bagi yang melanggar. Proses internalisasi nilai-nilai pendidikan Islam dapat membentuk sikap religius siswa SDIT Ghilmani. Hal ini ditunjukkan dengan meningkatnya sikap religius siswa ditinjau dari kedekatan terhadap Allah SWT melalui meningkatnya ibadah siswa, siswa berperilaku baik terhadap sesama dan terhadap alam sekitar. Selain itu, siswa menjadi mandiri, jujur, disiplin, sopan santun dan bertanggungjawab.

\section{Daftar Rujukan}

Abbas, Saleh. Pembelajaran Bahasa Indonesia yang Efektif di Sekolah Dasar. Jakarta: Departemen Pendidikan Nasional, 2006.

Ali, M. Pendidikan untuk Pembangunan Nasional: Menuju Bangsa Indonesia yang Mandiri dan Berdaya Saing Tinggi. Jakarta: Grasindo, 2009.

Alim, Muhammad, Pendidikan Agama Islam Upaya Pembentukan Pemikiran dan Kepribadian Muslim, Bandung: Remaja Rosdakarya, 2006.

Ilmugeografi.com. 10 Dampak Globalisasi di Bidang Pendidikan beserta contohnya. Artikel internet. https://www.google.com/amp/s/ilmugeografi.com/ilmusosial/dampak-globalisasi-di-bidang-pendidikan/amp. Diakses tanggal 23 September 2019

Jamil, Ahmad Islami. Pesat, Perkembangan Sekolah Islam Terpadu. Artikel internet di republika.co.id, 15 Juli 2017. Diakses 23 September 2019.

JSIT. Pengertian Sekolah Islam Terpadu. Artikel internet pada https://jsit-indonesia.com/sample-page/pengertian-sekolah-islamterpadu/ Diakses tanggal 23 September 2019.

Mahsun, Ali. "Pendidikan Islam dalam Arus Globalisasi: Sebuah Kajian Deskriptif Analitis". Episteme, Vol. 8, No. 2, (2013).

Majid, Abdul, Belajar dan Pembelajaran Pendidikan Agama Islam, Bandung: Remaja Rosdakarya, 2014.

Mulyasa, E., Manajemen Pendidikan Karakter. Bandung Rosdakarya. 2011. 
Mustari, Mohamad dan Rahman, M. T. Manajemen Pendidikan. Jakarta: RajaGrafika Persada, 2014.

Pusat Kurikulum. Pengembangan dan Pendidikan Budaya \& Karakter Bangsa: Pedoman Sekolah. Jakarta: TP, 2009.

Tafsir, Ahmad. Ilmu Pendidikan Islami. Bandung: Rosda Karya, 2010.

Sultoni, Achmad. "Implementasi Kurikulum 2013 Bidang Studi Biologi Dalam Mengembangkan Sikap Religius Siswa di Madrasah Aliyah". Jurnal Pendidikan Agama Islam (Journal of Islamic Education Studies), Vol. 4, No. 1 (2016).

Suradi, A. "Penanaman Religiusitas Keislaman Berorientasi pada Pendidikan Multikultural di Sekolah". Jurnal Pendidikan Agama Islam (Journal of Islamic Education Studies), Vol. 8, No. 1 (2018).

Safitri, Dewi. "Dampak Globalisasi terhadap Pendidikan". Jurnal Al Idarah; Jurnal Manajemen Pendidikan Islam, Vol. 1, No. 1 (2014). 